Egyptian Journal of Aquatic Biology \& Fisheries

Zoology Department, Faculty of Science,

Ain Shams University, Cairo, Egypt.

ISSN $1110-6131$

Vol. 24(3): 53 - 59 (2020)

www.ejabf.journals.ekb.eg

\title{
Length-weight relationship and relative condition factor of the Sultan fish, Leptobarbus hoevenii broodstock farmed in earthen ponds
}

\section{Sajeenuth Srithongthum ${ }^{1,2}$, Thumronk Amornsakun ${ }^{2}$, Poramat Musikarun ${ }^{3}$, Pornpanom Promkaew ${ }^{3}$, Hsein-Loong Au ${ }^{1,2}$, Gunzo Kawamura ${ }^{1}$, Mohammad T. M. Lal ${ }^{1}$, Leong-Seng Lim ${ }^{1}$ *}

1. Borneo Marine Research Institute, Universiti Malaysia Sabah, Jalan UMS, 88400 Kota Kinabalu, Sabah, Malaysia.

2. Fisheries Technology Program, Department of Technology and Industries, Faculty of Science and Technology, Prince of Songkla University, Pattani Campus, Mueang, Pattani, Thailand.

3. Inland Aquaculture Research and Development Regional Center 12, Khlong Hoy Kong, Amphoe Khlong Hoy Kong, Songkhla, 90230, Thailand.

*Corresponding Author: leongsen@ums.edu.my

\section{ARTICLE INFO}

Article History:

Received: Sept. 20, 2019

Accepted: April 28, 2020

Online: May 2020

Keywords:

Health condition ,

mad barb,

broodstock,

Leptobarbus hoevenii

Sultan fish,

Freshwater aquaculture.

\section{ABSTRACT}

The present study was aimed to assess the general health condition of Sultan fish, Leptobarbus hoevenii broodstock through their length-weight relationship (LWR) and relative condition factor (RCF). This broodstock was poly-cultured with the other carp's species in earthen ponds. Totally, 95 broodstock (35 females and 60 males) were examined in this study. The total length $(\mathrm{cm})$ and body weight $(\mathrm{g})$ ranges of the $L$. hoevenii broodstock were $32.8-43.0 \mathrm{~cm}$ and $460-1,400 \mathrm{~g}$ for the females, while $30.0-44.5$ $\mathrm{cm}$ and $285-1,300 \mathrm{~g}$ for the males, respectively. The $b$ value of the females was 3.10 (> 3.0), indicating that they have attained positive allometric growth. In opposite, the males and the overall populations have attained negative allometric growth as their $b$ value was 2.66 and $2.92(<3.0)$, respectively. All of these LWRs were significant at $\alpha=0.01$ with their correlation coefficient $(r)$ values at $0.88-0.90$. However, the $95 \%$ confidence intervals of these $b$ values were in the range of $2.32-3.64$; they included 3.0 and overlapped each other. This result showed that these $b$ values were not significantly different, indicating that the fish has achieved ideal growth. In addition, the relative condition factors of both females and males have achieved more than 1 (1.04 and 1.01, respectively), indicating that they have achieved their expected weight. Further observation on the LWR of the male L. hoevenii broodstock from the wild is necessary to confirm its optimum $b$ value. Overall, the $b$ value of the broodstock was 2.92 (close to 3 ), and their RCF value was 0.98 (close to 1 ). Therefore, the broodstock can be considered in good health condition. However, the influence of poly-culture management on the LWR of this broodstock should be examined in future studies. 


\section{INTRODUCTION}

Sultan fish or the Jelawat, Leptobarbus hoevenii, is a cyprinid that can be naturally found in lakes and rivers in certain Southeast Asian countries, including Malaysia, Cambodia, Indonesia, Laos, and Thailand (Mohsin and Ambak, 1983; Roberts, 1989; Rainboth, 1996; Vidthayanon et al., 1997; Kottelat, 2001). The captive breeding of $L$. hoevenii has been successful since 1980s (Meenakarn, 1986; Saidin et al., 1988; Liao et al., 2000), and it is one of those with the high commercial value, among the cyprinids that have been successfully bred for aquaculture (Mohsin and Ambak, 1983; Kottelat et al., 1993).

In Songkhla Province of the southern Thailand, the seed production of freshwater fishes, including L. hoevenii, has been regularly carried out by the Inland Aquaculture Research and Development Regional Center 12, to supply seedlings to the local farmers for fattening and sales. Although this center has continuously supplied the L. hoevenii seedlings to farmers since 1993, the general health condition of the L. hoevenii broodstock has never been assessed. In this center, the L. hoevenii broodstock are polycultured with the other cyprinids (mainly the common carp, Cyprinus carpio, and the Rohu carp, Rohu rohita) in the earthen ponds. It is unknown that whether these broodstock are growing well in the ponds with the poly-culture system implemented; or in other say, are the current pond farming practices suitable to optimize the broodstock health condition?

Length-weight relationship (LWR) evaluation is a common way to assess the general health condition of the cultured aquatic animals. LWR can reflect the degree of wellbeing and adaptability of the animals to their farming environment (Hassan and Javed, 1999; Olurin and Aderibigbe, 2006; Lim et al., 2013; Kumar et al., 2014). Derived from the LWR calculation, the relative condition factor (RCF) can be calculated to determine if the observed condition of the animal were up to the expected condition (Fafuiye and Oluajo, 2005; Farzana and Saira, 2008; Lim et al., 2013).

The present study, therefore, was aimed to estimate the LWR and RCF of the earthen ponds farmed $L$. hoevenii broodstock in the Inland Aquaculture Research and Development Regional Center 12, in order to assess their general health condition. The outcomes of this study provide knowledge to the center management about the broodstock condition, and allow them to improve whichever protocol that is necessary.

\section{MATERIALS AND METHODS}

\section{Broodstock Rearing Conditions}

The L. hoevenii broodstock used in this study were obtained from the earthen ponds, operated by the Inland Aquaculture Research and Development Regional Center 12, Songkhla, Thailand. Those broodstock were poly-cultured with other species of carps as mentioned earlier. They were hand-fed until satiation twice a day with commercial compounded feed (Speed Brand, Thailand, crude protein lipid levels were 30\% and 3\%, respectively). The lowest and the highest water temperatures in the earthen ponds were recorded at $25^{\circ} \mathrm{C}$ in the morning $(09: 00)$ and at $33^{\circ} \mathrm{C}$ in the afternoon (15:00). 


\section{Fish Sampling and Measurements}

A total of $95 \mathrm{~L}$. hoevenii broodstock were sampled from the earthen ponds, and transferred to the roofed area at the ponds side. The fish were anesthetized, then individually, their body surface were mopped dry with a towel. Subsequently, the total length (TL in centimeters) and body weight (BW in grams) of each fish were measured using a tape ruler and a balance, respectively. During the measurement, the fish genders were also determined through visual observation on the fish genital pore, and the results were recorded.

\section{Calculations of LWR and RCF}

In this study, the LWRs of the female, male, and overall populations were calculated. The LWRs were calculated with the formula $\mathrm{W}=\mathrm{a} \mathrm{L}^{\mathrm{b}}$, where $\mathrm{W}=$ fish body weight and $\mathrm{L}=$ fish total length (Ricker, 1973). The formula were logarithm-transformed to $\ln \mathrm{W}=\ln$ $a+b \ln \mathrm{L}$, then the linear regression graph was plotted using MS-Excel computer program to estimate the values of the constant $(a)$, slope $(b)$, the correlation coefficient $(r)$ (and its significant level) of the LWRs. The growth condition of the fish was then categorized using the $b$ values; when $b=3$, the fish has attained isometric growth, $b<3$ indicated negative allometric, and $b>3$ indicated positive allometric growth (Lim et al. 2013).

The RCF calculation was performed by using formula $\mathrm{Kn}=\mathrm{W} / \mathrm{W}$ ' where $\mathrm{W}$ is the observed weight, and $\mathrm{W}^{\prime}$ is the expected weight of individual fish $\left(\mathrm{a} \mathrm{L}^{\mathrm{b}}\right)$ with the earlier estimated $b$ value (Fafuiye and Oluajo, 2005; Farzana and Saira, 2008; Lim et al., 2013). If $\mathrm{Kn}=1$ or more, this outcome indicated that the fish has achieved the expected growth, and vice versa.

\section{RESULTS AND DISCUSSION}

The LWR linear regression graphs of the female, male, and overall L. hoevenii broodstock populations are shown in Figure 1, while the estimated parameters of these LWRs are summarized in Table 1. In the female, male, and overall populations, their correlation coefficients $r(0.88-0.90)$ were significantly high at $\alpha=0.01$, showing that the calculated values of $\ln a$ and slope $b$ were statistically significant. Since the standard deviations of $b$ values were similar among all these populations, the calculation of $95 \%$ confidence interval of $b$ value of each population was possible, and they are shown in Table 1. From these results, it was found that the female population has achieved positive allometric growth as its $b$ value was 3.10 (> 3), while opposite result was noticed in the male population; the male fish has attained negative allometric growth as its $b$ value was $2.66(<3)$. The $b$ value of the overall population (2.92) also showed negative allometric growth. However, the $95 \%$ confidence intervals from all populations were in the range that included 3.0, and they overlapped each other. This result showed that the $b$ values from all populations were not significantly different at $\alpha=0.05$; indicating that both female and male populations have achieved the ideal growth. Froese et al. (2014) has estimated the LWRs of 32000 species of fishes recorded in FishBase using the Bayesian approach and estimated that the $b$ value of L. hoevenii to be 3.12. This $b$ value is larger than those obtained in the present study, and such outcome could be due to the smaller size of fish (TL $2.94-3.30 \mathrm{~cm}$ ) examined by Froese et al. (2014). Indeed, younger specimens tend to show larger $b$ values than adult in a given population and species of 
fish (Froese, 2006). Other than that, it was interesting to find that the RCFs from both female and male populations were larger than 1 (1.04 and 1.01, respectively) as shown in Table 2, suggesting that both fish populations have achieved their expected growth. In fact, fish sex may has influence on its LWR because the female and male fishes will invest different energy amounts into gonad development and growth at different times of year (Le Cren, 1951). Besides, there is still no report on any L. hoevenii LWR observation from the wild.
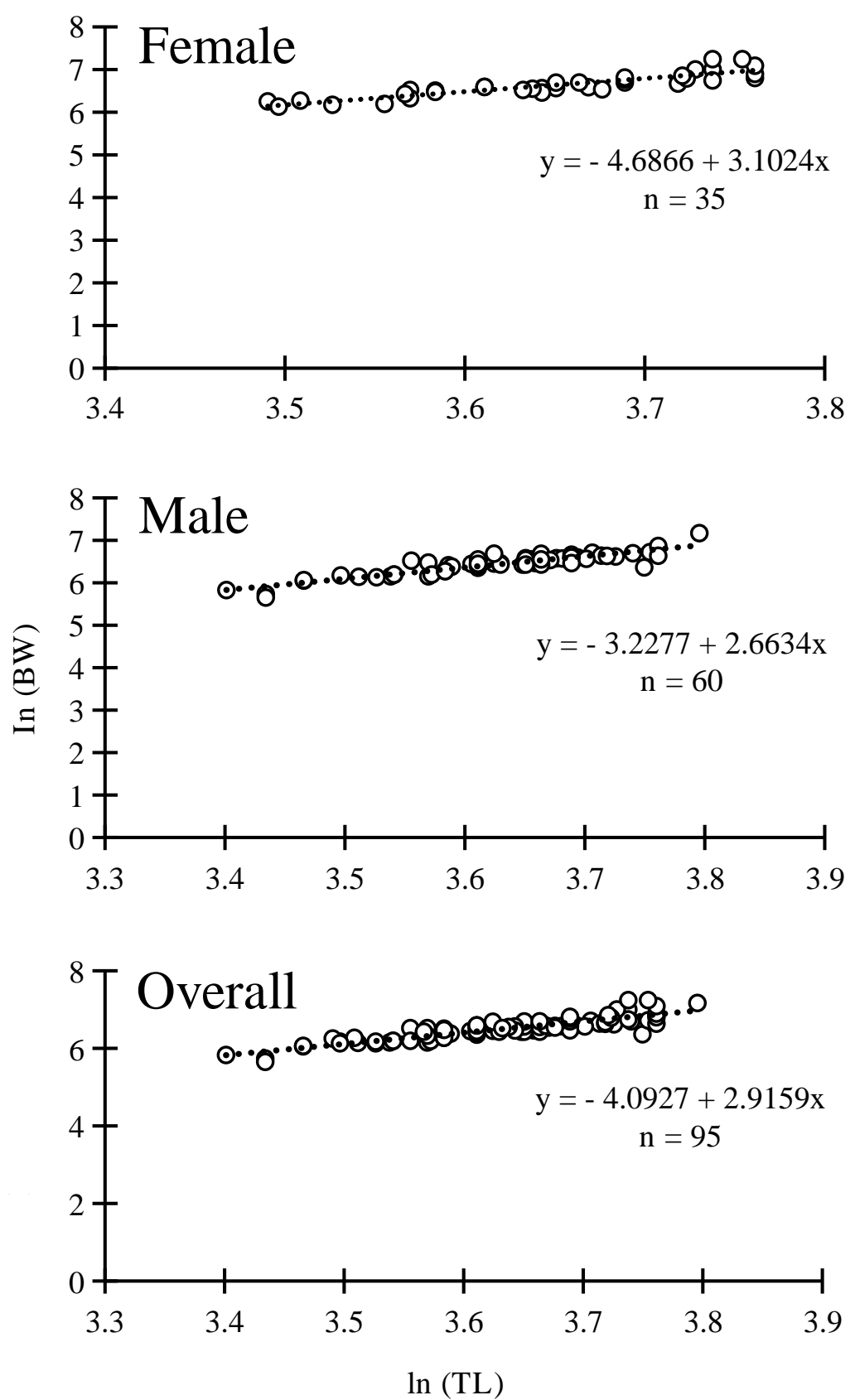

Figure 1. Linear regression graphs for the LWR of the female, male, and overall populations of the earthen pond-farmed L. hoevenii broodstock. 
Therefore, it is hard to conclude that the farmed male L. hoevenii broodstock observed in this study was not in their optimum health condition. In fact, Jellyman et al. (2013) also found that the wild male $C$. carpio has its $b$ value lesser than 3 while the female's one was larger than 3. Further observation on the LWR of L. hoevenii from wild is therefore recommended for future study.

Table 1. Estimated parameters in the length-weight relationship of the pond-farmed $L$. hoevenii broodstock through regression analysis.

\begin{tabular}{|c|c|c|c|c|c|c|c|c|c|c|}
\hline \multirow{2}{*}{ Category } & \multirow{2}{*}{$\mathbf{n}$} & \multicolumn{2}{|c|}{ Body Weight (g) } & \multicolumn{2}{|c|}{ Total Length (cm) } & \multirow{2}{*}{$\ln a$} & \multirow[b]{2}{*}{$\boldsymbol{b}$} & \multirow[b]{2}{*}{ S.D. of $b$} & \multirow[b]{2}{*}{$95 \%$ of C. I. } & \multirow[b]{2}{*}{$\mathbf{r}$} \\
\hline & & Min & Max & Min & Max & & & & & \\
\hline Female & 35 & 460.0 & 1400.0 & 32.8 & 43.0 & -4.69 & 3.10 & 1.538 & $2.56-3.64$ & $0.90^{*}$ \\
\hline Male & 60 & 285.0 & 1300.0 & 30.0 & 44.5 & -3.23 & 2.66 & 1.317 & $2.32-3.01$ & $0.90^{*}$ \\
\hline Overall & 95 & 285.0 & 1400.0 & 30.0 & 44.5 & -4.09 & 2.92 & 1.657 & $2.58-3.24$ & $0.88^{*}$ \\
\hline
\end{tabular}

$\mathrm{N}=$ number of specimens, $\min =$ minimum, $\max =$ maximum, $\mathrm{a}=$ intercept of regression line, $\mathrm{b}=\mathrm{slope}$ of regression line, S.D. = standard deviation, C. I. = confidence interval, $\mathrm{r}=$ correlation coefficient, ${ }^{*}$ significant at $\alpha=0.01$

Table 2. The observed, expected body weight and relative condition factor of the female, male and overall L. hoevenii broodstock populations examined in this study.

\begin{tabular}{lccc}
\hline Populations & $\begin{array}{c}\text { W } \\
\text { (Observed body weight } \boldsymbol{~} \mathbf{g})\end{array}$ & $\begin{array}{c}\text { W } \\
\text { (Expected body weight }-\mathbf{g})\end{array}$ & $\begin{array}{c}\text { Kn } \\
\text { (Relative condition factor) }\end{array}$ \\
\hline Female & $792.94 \pm 233.75$ & $760.30 \pm 182.24$ & $1.04 \pm 0.13$ \\
Male & $640.43 \pm 159.84$ & $634.28 \pm 139.30$ & $1.01 \pm 0.12$ \\
Overall & $696.62 \pm 203.15$ & $712.70 \pm 167.99$ & $0.98 \pm 0.14$ \\
\hline
\end{tabular}

Despite the negative allometric growth observed in the male broodstock population, the $b$ value of the overall fish population was close to 3 (2.92), indicating the fish was in healthy condition generally. Nevertheless, the influences of poly-culture (stocking ratio among the species) to the LWR of these broodstock should be examined in the near future as such influence may be the key point to the management to promote optimal health condition of the fish. Indeed, Haruna and Ipinjolu (2013) have reported that the 1: 6 of Clarias to Tilapia was the best ratio to promote the growth of these fishes, compared to the mono-culture and the other stocking ratios tested.

\section{CONCLUSION}

In conclusion, the female $L$. hoevenii broodstock has achieved positive allometric growth hence it was considered healthy. However, negative allometric growth was found in the male broodstock; it might be said that the fish was not in their optimum health condition but such confirmation only can be made when information on the LWR of the wild $L$. hoevenii is available to compare. Despite that, the overall L. hoevenii broodstock was considered in good health as their growth was close to isometric. 


\section{ACKNOWLEDGEMENT}

This study was funded by the research grant UMSGREAT (GUG0380-1/2019), provided by the Research and Innovation Management Center of Universiti Malaysia Sabah (UMS). The first author also thanks to UMS and Prince of Songkla University (PSU) Pattani Campus for providing scholarships to support her study under the UMS PSU Dual Master Degrees Program.

\section{REFERENCES}

Fafuiye, O. O. and Oluajo, O. A. (2005). Length-weight relationships of five fish species in Epe Lagoon, Nigeria. African Journal of Biotechnology, 4(7): 749-751.

Farzana, Y. and Saira, K. (2008). Length-weight relationship and relative condition factor for the Halfbeak Hemiramphus far Forsskål, 1775 from the Karachi Coast. University Journal of Zoology, Rajshahi University, 27: 103-104.

Froese, R. (2006). Cube law, condition factor and weight-length relationships: history, meta-analysis and recommendations. Journal of Applied Ichthyology, 22: 241-253.

Froese, R.; Thorson, J. T. and Reyes Jr., R. B. (2014). A Bayesian approach for estimating length-weight relationships in fishes. Journal of Applied Ichthyology, 30: 78-85.

Haruna, M. A. and Ipinjolu, J. K. (2013). Length-weight relationship and condition factor in the polyculture of Clarias and tilapia in concrete tanks. Bayero Journal of Pure and Applied Sciences, 6(2): 132-135.

Hassan, M. and Javed, M. (1999). Length-weight relationships and condition factor studies in three major carps reared under integrated polyculture system. Pakistan Journal of Biological Sciences, 2(4): 1620-1622.

Jellyman, P. G.; Booker, D. J.; Crow, S. K.; Bonnett, M. L. and Jellyman, D. J. (2013). Does one size fit all? An evaluation of length-weight relationships for New Zealand's freshwater fish species. New Zealand Journal of Marine and Freshwater Research, 47(4): 450-468.

Kottelat, M. (2001). Fishes of Laos. WHT Publications Ltd., Colombo, Sri Lanka.

Kumar, P.; Pandey, N. N.; Okendro Singh, N.; Chandra, N.; Mishra, D. C.; Agrawal, P. K.; Barat, A. and Bhatt, J. C. (2014). Length-weight relationship and growth pattern of common carp (Cyprinus carpio var. communis) in different pond environment in Mid Hill region. Journal of Ecophysiology and Occupational Health, 14: $48-54$. 
Le Cren, E. D. (1951). The length-weight relationship and seasonal cycle in gonad weight and condition in perch (Perca fluviatilis). Journal of Animal Ecology, 20: 201-219.

Liao, I. C.; Su, H. M. and Chang, E. Y. (2000). Techniques in finfish larviculture in Taiwan. Aquaculture, 200: 1-31.

Lim, L. S.; Chor, W. K.; Tuzan, A. D.; Malitam, L.; Gondipon, R. and Ransangan, J. (2013). Length-weight relationships of the pond-cultured spotted barb (Puntius binotatus). International Research Journal of Biological Sciences, 2(7): 61-63.

Meenakarn, S. (1986). Induced Spawning on Leptobarbus hoevenii (Bleeker) Carried out in Jambi, Indonesia. Collaborative Project of the Directorate General of Fisheries, Indonesia and the United States Agency for International Development (Final Report of Small-Scale Fisheries Development Project. Cage Culture and Seed Production Sub-Project. USAID/ARD Project no. 497-0286). The Directorate General of Fisheries, Jakarta, Indonesia.

Mohsin, A. K. M. and Ambak, M. A. (1983). Freshwater Fishes of Peninsular Malaysia. Universiti Putra Malaysia, Serdang, Malaysia.

Olurin, K. B. and Aderibigbe, O. A. (2006). Length-weight relationship and condition factor of pond reared juvenile Oreochromis niloticus. World Journal of Zoology, 1(2): 82-85.

Rainboth, W. J. (1996). FAO Species Identification Field Guide for Fishery Purposes, Fishes of the Cambodian Mekong, Food and Agriculture Organization of the United Nations, Rome.

Ricker, W. E. (1973). Linear regression in fisheries research. Journal of the Fisheries Research Board of Canada, 30: 409-434.

Roberts, T. R. (1989). Memoirs of the Southern California Academy of Sciences Volume 14 - The Freshwater Fishes of Western Borneo (Kalimantan Barat, Indonesia). The Academy, San Francisco.

Saidin, T. B.; Othman, A. A. B. and Sulaiman, M. Z. B. (1988). Induced spawning techniques practiced at Batu Berendam, Melaka, Malaysia. Aquaculture, 74: 23-33.

Vidthayanon, C.; Karnasuta, J. and Nabhitabhata, J. (1997). Diversity of Freshwater Fishes in Thailand. Office of Environmental Policy and Planning, Bangkok, Thailand. 